University of Nebraska - Lincoln

DigitalCommons@University of Nebraska - Lincoln

Faculty Papers and Publications in Animal

Science

Animal Science Department

2001

Conjugated Linoleic Acid (CLA), Body Fat, and Apoptosis

Jess L. Miner

University of Nebraska-Lincoln, jminer1@unl.edu

C. Cederberg

University of Nebraska-Lincoln

Merlyn K. Nielsen

University of Nebraska-Lincoln, mnielsen1@unl.edu

Xiaoli Chen

University of Georgia, Athens, Georgia

Clifton Baile

University of Georgia, Athens, Georgia

Follow this and additional works at: https://digitalcommons.unl.edu/animalscifacpub

Part of the Animal Sciences Commons

Miner, Jess L.; Cederberg, C.; Nielsen, Merlyn K.; Chen, Xiaoli; and Baile, Clifton, "Conjugated Linoleic Acid (CLA), Body Fat, and Apoptosis" (2001). Faculty Papers and Publications in Animal Science. 578.

https://digitalcommons.unl.edu/animalscifacpub/578

This Article is brought to you for free and open access by the Animal Science Department at DigitalCommons@University of Nebraska - Lincoln. It has been accepted for inclusion in Faculty Papers and Publications in Animal Science by an authorized administrator of DigitalCommons@University of Nebraska - Lincoln. 


\title{
Conjugated Linoleic Acid (CLA), Body Fat, and Apoptosis
}

\author{
Jess L. Miner, ${ }^{a}$ Chris A. Cederberg, ${ }^{a}$ Merlyn K. Nielsen, ${ }^{a}$ Xiaoli Chen, ${ }^{b}$ and Clifton A. Baile ${ }^{b}$ \\ a University of Nebraska-Lincoln, Lincoln, Nebraska \\ b University of Georgia, Athens, Georgia
}

Corresponding author - Dr. Jess L. Miner, Animal Science Department

University of Nebraska-Lincoln, Lincoln, NE 68583-0908. Email jminer1@unl.edu

\begin{abstract}
Objective: The objective of the study was to determine if consumption of conjugated linoleic acid (CLA) by mice could induce apoptosis in adipose tissue. Other objectives were to determine the influence of feeding mice CLA for $\leq 2$ weeks on body fat, energy expenditure, and feed intake.

Research Methods and Procedures: A mixture of CLA isomers (predominantly $\mathrm{c} 9, \mathrm{t} 11$ and $\mathrm{t} 10, \mathrm{c} 12$ ) was included in the AIN-93G diet at 0,1 , and $2 \%$, and fed to mice for 12 days (Trial 1), or was included at $2 \%$ and fed to mice for 0,5 , and 14 days (Trial 2). Feed intake was measured daily and energy expenditure was determined by direct calorimetry on day 9 in Trial 1. Retroperitoneal fat pads were analyzed for apoptosis by determination of DNA fragmentation.

Results: Dietary CLA reduced feed intake by $10 \%$ to $12 \%(p<$ $0.01)$, but either did not influence or did not increase energy expenditure as indicated by heat loss. Body weight was not influenced by consumption of CLA in Trial 1 but was increased $(p<0.01)$ by CLA in Trial 2 . Weights of retroperitoneal, epididymal, and brown adipose tissues were lower $(p<0.01)$ in animals fed CLA, although liver weight was increased $(p<0.10$; Trial 1) or not changed (Trial 2). Analysis of retroperitoneal fat pad DNA from both trials indicated that apoptosis was increased $(p<0.01)$ by CLA consumption.

Discussion: These results are interpreted to indicate that CLA consumption causes apoptosis in white adipose tissue. This effect occurs within 5 days of consuming a diet that contains CLA.
\end{abstract}

Keywords: mouse, food intake, conjugated linoleic acid, apoptosis, body fat

\section{Introduction}

Several prominent health benefits have been attributed to consumption of conjugated linoleic acid (CLA). In rodents, dietary CLA stops cancer growth (1), improves glucose tolerance (2), reduces body fat, and increases oxygen consumption (3) (4) (5). The mechanism by which CLA mediates any of these benefits is yet to be determined. However, Ip et al. (1) observed that an inhibitory effect of CLA on mammary epithelial cell growth was associated with apoptosis. This clue, coupled with the observation that centrally administered leptin can cause apoptosis of adipocytes (6), led us to test the hypothesis that dietary CLA causes apoptosis of adipocytes. We also determined effects of dietary CLA in lines of mice that differed genetically with regard to obesity.

\section{Research Methods and Procedures}

\section{Materials}

Male MH (12 weeks of age; $n=30)$, ML (12 weeks of age; $n=30)$, C57BL/6J (10 weeks of age; $n=30$ ) and M16 (retired breeders 26 to 30 weeks of age; $n=20$ ) were obtained from our colony. The $\mathrm{MH}$ and $\mathrm{ML}$ mice were generated by selection for high and low heat loss, respectively (7) (8). The MH mice emit $60 \%$ more heat than ML mice, are leaner, and consume more feed. However, $\mathrm{MH}$ and ML mice are not different in body weight at any age up to at least 16 weeks. The M16 mice were generated by selection for maximum body weight gain during 3 to 6 weeks of age (9). These mice exhibit obesity relative to unselected controls (10). The C57BL/6J mice from our colony are from the Jackson Laboratories colony (Bar Harbor, ME). The C57BL/6J mice are similar to ML mice with regard to low heat loss and feed intake but similar to $\mathrm{MH}$ mice with regard to low body fatness. The growth rate of this inbred strain is slower than that of the other strains used in this study (11). Animal procedures were conducted as approved by the Uni- 


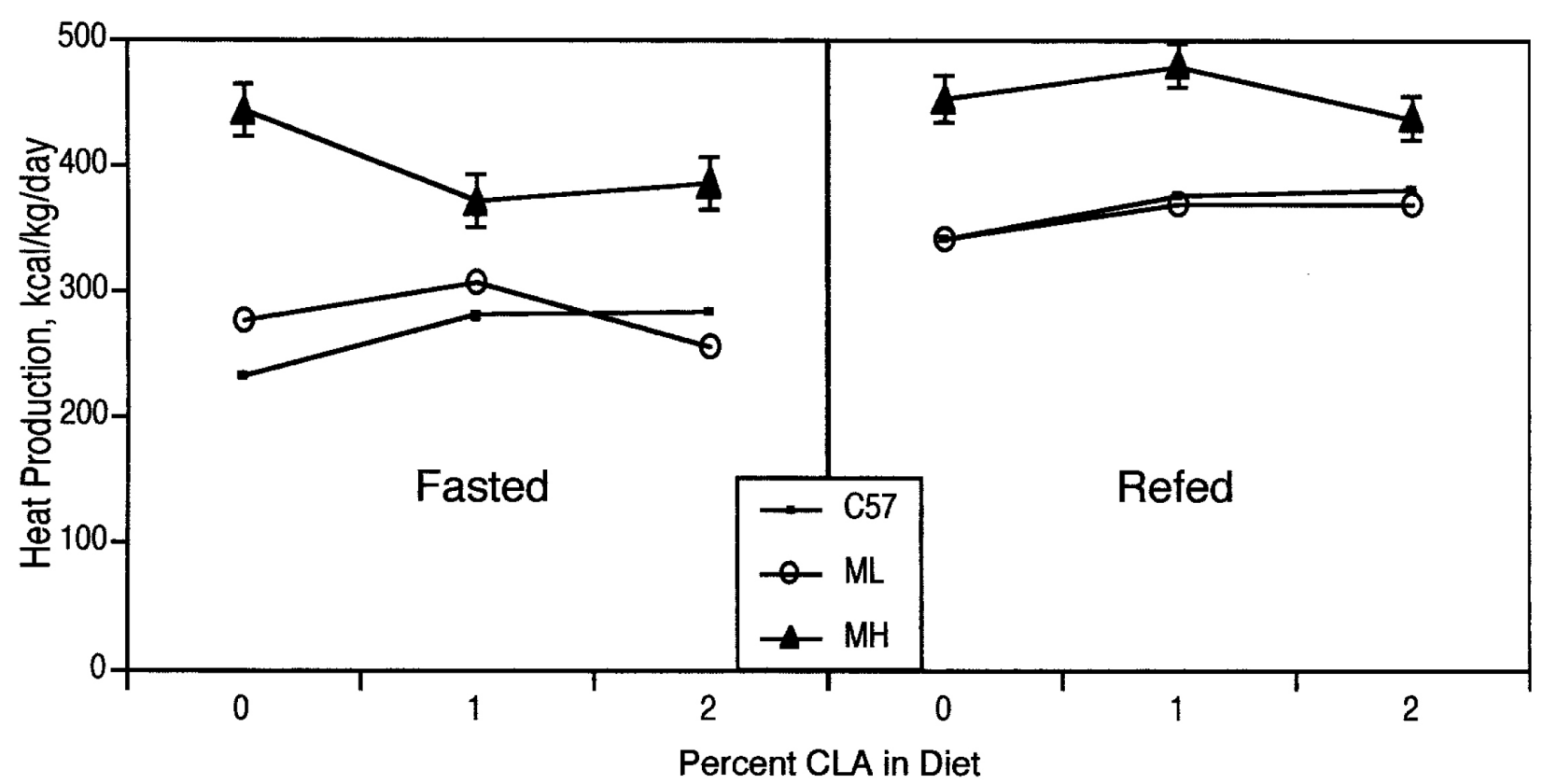

Figure 1. Heat loss, Trial 1. In the fasted state, genetic line $(p<0.01)$ and genetic line by CLA interaction $(p<0.02)$ are significant, but CLA is not $(p>0.5)$. In the refed state, line is significant $(p<0.01)$; CLA $(p=0.13)$ and line by CLA interaction $(p>0.5)$ are not significant. SEM was 22 and 18 for fasted and refed states, respectively.

versity of Nebraska Institutional Animal Care and Use Committee.

CLA (95\% conjugated diene) was purchased from Nu-Chek-Prep (Elysian, MN) and mixed into a purified base diet (AIN-93G) by Dyets, Inc. (Bethlehem, PA). Soy oil was replaced with CLA $(1: 1, w / w)$ to create the following diets: 1) $0 \%$ CLA, $7 \%$ soy oil; 2) $1 \%$ CLA, $6 \%$ soy oil; and 3) $2 \%$ CLA, $5 \%$ soy oil. The CLA is reported by the manufacturer to be $44 \% \mathrm{t} 10, \mathrm{c} 12 ; 10 \% \mathrm{c} 10, \mathrm{c} 12 ; 41 \%$ $\mathrm{c} 9, \mathrm{t} 11 / \mathrm{t} 9, \mathrm{c} 11$; and $5 \%$ other isomers.

\section{Protocol}

The experiment was composed of two trials. In Trial 1, $\mathrm{MH}, \mathrm{ML}$, and C57BL/6J mice were housed individually at $22{ }^{\circ} \mathrm{C}$, under a photoperiod of 12 hours light and 12 hours dark (lights out at 7:00 PM), and fed AIN-93G diet for 1 week before data collection. Mice were randomly assigned to one of the three experimental diets that were fed for 12 days. There were 10 replications of the nine diet-by-line combinations. Experimental diets were fed to the nine mice of the first replicate on day 1 of the study. On day 2 , the second replicate started to consume the experimental diet and so forth, so that by day 10 all 90 animals were consuming the experimental diet.

Direct calorimetry was used to measure heat loss during a 4-hour period beginning at 5:00 PM on day 9 for each replicate. A detailed description of our calorimetry method has been published elsewhere (7). Briefly, the mice were placed individually into direct calorimeters (Thermonetics Corp., San Diego, CA), which mea- sure voltage change that results from movement of heat energy through the walls of the calorimeters. On the day of calorimetry, feed was unavailable from 12:00 AM until 7:00 PM. Thus, heat loss was determined in the fasted and in the refed state for each animal. Heat loss was determined at 1-minute intervals for 2 hours in each state. Water was not available in the calorimeter chambers.

Three days after calorimetry, between 8:00 AM and 10:00 AM, mice were killed by $\mathrm{CO}_{2}$ asphyxia. Livers, brown epididymal, and retroperitoneal fat pads were removed and weighed. The liver and brown fat pad from each mouse were further analyzed for lipid content by extraction with chloroform:methanol $(2: 1, \mathrm{v} / \mathrm{v})$ and $0.05 \%$ sulfuric acid (12). Retroperitoneal fat pads from animals fed 2\% CLA $(n=12)$ and from animals fed the control diet $(n=9)$ were frozen in liquid nitrogen and stored $\left(-80^{\circ} \mathrm{C}\right)$ until being analyzed for apoptosis.

In Trial 2, 20 M16 mice were randomly allocated to three treatments and fed either $0 \%$ CLA for 14 days $(n=$ 7), $0 \%$ CLA for 9 days and then 2\% CLA for 5 days ( $n=$ $6)$, or $2 \%$ CLA for 14 days $(n=7)$. Body weight change was recorded and tissues were weighed and assayed for apoptosis as in Trial 1.

\section{Apoptosis Assays}

Apoptosis assay was based on internucleosomal DNA degradation (6). Retroperitoneal fat pads were homogenized in digestion buffer $(100 \mathrm{mM} \mathrm{NaCl}, 10 \mathrm{mM}$ tris( hydroxymethyl)aminomethane- $\mathrm{HCl}[\mathrm{pH} 8.0], 25 \mathrm{mM}$ EDTA, $0.5 \%$ sodium dodecyl sulfate, and $0.2 \mathrm{mg} / \mathrm{ml}$ 
Table 1. Heat loss in fasted and refed mice as influenced by genetic line and dietary CLA expressed on a 24-hour basis either per animal, per body weight $(\mathrm{kg})$, or per exponent of body weight $\left(\mathrm{kg}^{75}\right)$ in Trial 1.

\begin{tabular}{|c|c|c|c|c|c|c|}
\hline \multirow[b]{2}{*}{ Main effect } & \multicolumn{3}{|c|}{ Fasted } & \multicolumn{3}{|c|}{ Refed } \\
\hline & Heat & Heat/BW & Heat/BW ${ }^{75}$ & Heat & Heat/BW & Heat/BW ${ }^{75}$ \\
\hline \multicolumn{7}{|l|}{ Line } \\
\hline C57 & 7.0 & 266 & 107 & 9.6 & 366 & 147 \\
\hline ML & 10.4 & 279 & 123 & 13.4 & 360 & 158 \\
\hline MH & 14.4 & 400 & 174 & 16.5 & 456 & 199 \\
\hline SEM & $\begin{array}{c}0.43 \\
(p<0.01)^{*}\end{array}$ & $\begin{array}{c}12.3 \\
(p<0.01)\end{array}$ & $\begin{array}{c}5.2 \\
(p<0.01)\end{array}$ & $\begin{array}{c}0.39 \\
(p<0.01)\end{array}$ & $\begin{array}{c}10.3 \\
(p<0.01)\end{array}$ & $\begin{array}{c}4.4 \\
(p<0.01)\end{array}$ \\
\hline \multicolumn{7}{|l|}{ CLA } \\
\hline $0 \%$ & 11.0 & 317 & 137 & 12.9 & 378 & 162 \\
\hline $1 \%$ & 10.7 & 320 & 136 & 13.7 & 408 & 174 \\
\hline $2 \%$ & 10.0 & 308 & 131 & 12.9 & 396 & 168 \\
\hline SEM & $\begin{array}{c}0.43 \\
(p>0.2)\end{array}$ & $\begin{array}{c}12.3 \\
(p>0.5)\end{array}$ & $\begin{array}{c}5.2 \\
(p>0.5)\end{array}$ & $\begin{array}{c}0.39 \\
(p>0.2)\end{array}$ & $\begin{array}{c}10.3 \\
(p=0.13)\end{array}$ & $\begin{array}{c}4.4 \\
(p=0.18)\end{array}$ \\
\hline
\end{tabular}

BW, body weight.

* Significance of main effect.

proteinase K), nuclei and cellular debris were removed by centrifugation, and the supernatant was incubated at $55{ }^{\circ} \mathrm{C}$ overnight. The supernatant was then extracted once with phenol:chloroform:isoamyl alcohol (25:24:1) and twice with chloroform/isoamyl alcohol and then precipitated in ethanol. The DNA was resuspended in tris(hydroxymethyl)aminomethane-EDTA buffer and treated with $0.1 \mathrm{U}$ of deoxyribonuclease-free ribonuclease. One microgram of normalized DNA was labeled with $\left[{ }^{32} \mathrm{P}\right]$ deoxycytidine triphosphate using the Klenow fragment of DNA polymerase I, extracted, separated by agarose gel electrophoresis, and viewed by autoradiography for the laddering pattern that is characteristic of apoptosis. The intensity of signals for the fragment of high molecular weight and fragments of low molecular weight in each sample were quantified by image analysis. The percentage of the intensity for low molecular weight fragments versus the high molecular weight fragment was expressed as the degree of DNA fragmentation.

\section{Data Analyses}

Heat loss (kilocalories per day) and feed intake (grams per day) were analyzed based on animal, body weight $(\mathrm{kg})$, and exponent of body weight $\left(\mathrm{kg}^{75}\right)$. The General Linear Models procedure of Statistical Analysis System (13) was used to compute ANOVA. For heat loss, the model included effects of CLA level, genetic line, genetic line by CLA interaction, and animal within CLA level-genetic line class. Heat loss was analyzed separately for the fed state and for the fasted state. Feed in- take and body weight analyses included the mentioned effects plus the effect of day. Mean squares for animal within CLA level-genetic line class were used as denominator of the $F$ test for CLA level, genetic line, and CLA level by genetic line interaction effects. Tissue weights and apoptosis were analyzed similarly except that the model did not include animal, and the residual mean squares were used to determine significance. Apoptosis data were transformed by raising to the one-third power to meet the ANOVA assumption of homogeneous variance.

Table 2. Feed intake (grams per day) expressed either per animal, per body weight $(\mathrm{kg})$, or per exponent of body weight $\left(\mathrm{kg}^{75}\right)$ in Trial 1.

\begin{tabular}{lccc}
\hline Main effect & Feed intake & Feed/BW & Feed $/ \mathrm{BW}^{75}$ \\
\hline Line & & & \\
C57 & 4.2 & 159 & 64 \\
ML & 4.5 & 121 & 53 \\
MH & 5.5 & 153 & 66 \\
SEM & 0.11 & 3.7 & 1.5 \\
& $(p<0.01)^{*}$ & $(p<0.01)$ & $(p<0.01)$ \\
CLA & & & \\
0\% & 5.0 & 153 & 65 \\
1\% & 4.7 & 144 & 61 \\
$2 \%$ & 4.4 & 137 & 58 \\
SEM & 0.11 & 3.7 & 1.5 \\
& $(p<0.01)$ & $(p<0.01)$ & $(p<0.01)$ \\
\hline
\end{tabular}

BW: body weight.

* Significance of main effect. 


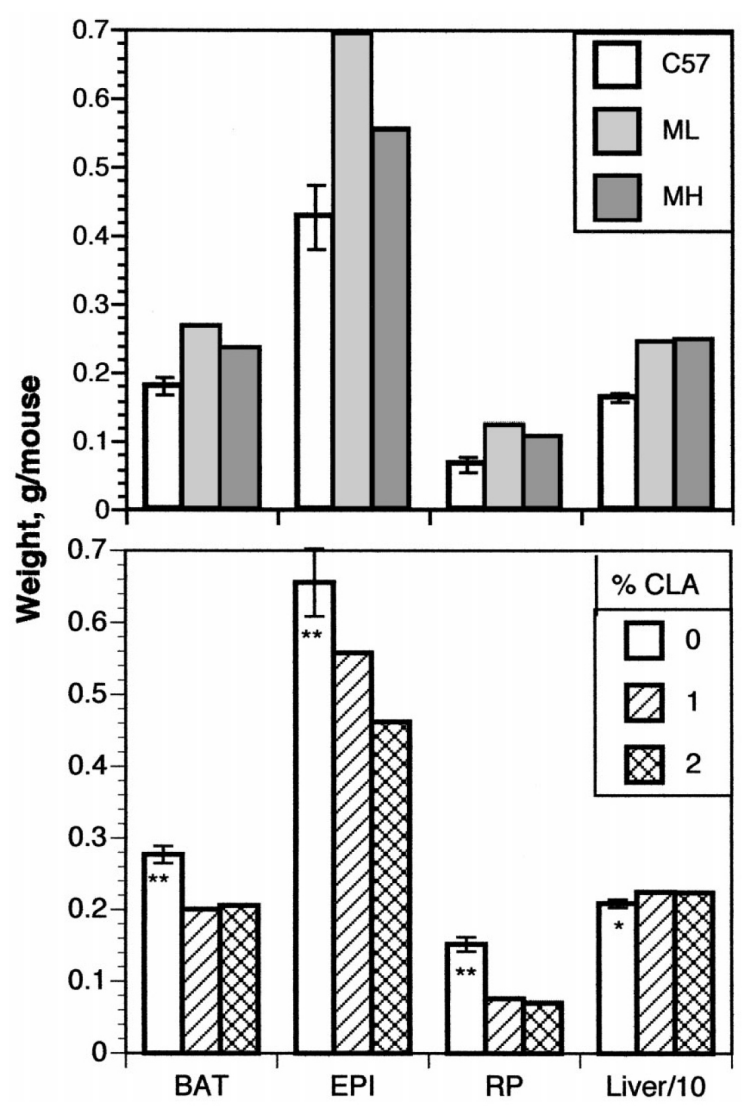

Figure 2. Trial 1, weight of brown (BAT), epididymal (EPI), and retroperitoneal (RP) fat pads and of the liver (scaled to $10 \%$ of actual weight) as influenced by line (top) and dietary CLA (bottom). Genetic line affected all tissues $(p<0.01)$. ${ }^{* *}$ CLA effect $(p<0.01)$. *CLA effect $(p<0.10)$. Genetic line by CLA interaction was not significant for all tissues $(p>0.5)$. Error bars represent SEM.

\section{Results and Discussion}

\section{Heat Loss and Feed Intake (Trial 1)}

We expected that feeding mice CLA would stimulate heat production because West et al. (4) had reported that it increases oxygen consumption. Their mice consumed feed ad libitum, so we used a similar protocol. Our heat loss results are presented in Figure 1 and Table 1. Feed intake results are presented in Table 2. Results in Tables 1 and 2 are presented based on animal, body weight, and an exponential function of body weight commonly considered to be "metabolic body weight" (weight ${ }^{75}$ ), because there is some controversy as to which is appropriate, especially when comparing energy expenditure with feed consumption (14). In fasted mice, regardless of denominator used for expressing the results, the genetic line by CLA interaction indicated that CLA suppresses heat loss in $\mathrm{MH}$ mice but stimulates heat loss in ML and C57BL/6J mice (Figure $1 ; p<0.05$ ). The magnitude of this interaction is small and its biological significance is

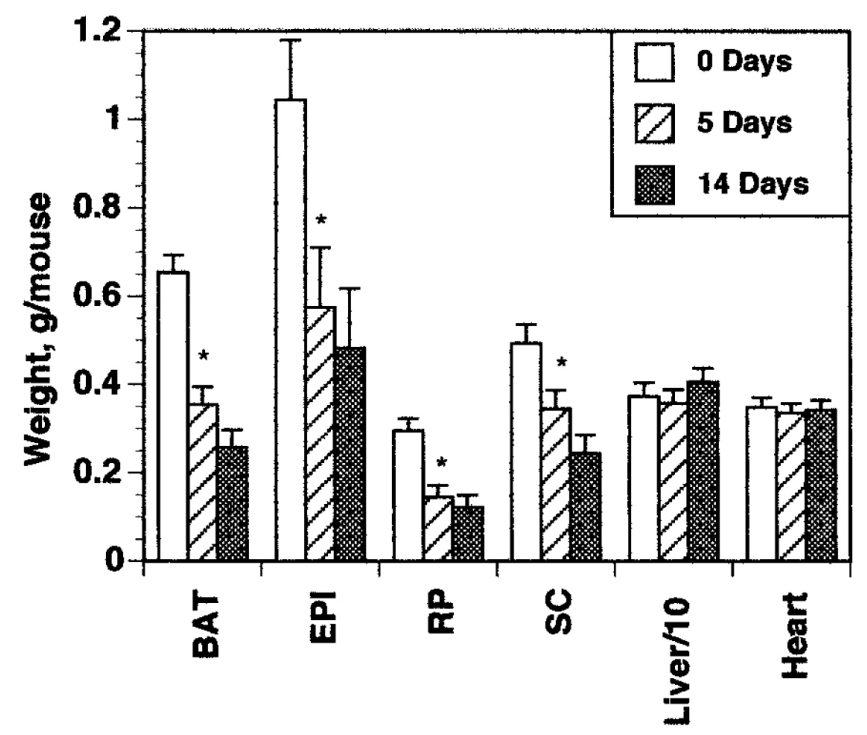

Figure 3. Trial 2, weight of brown (BAT), epididymal (EPI), retroperitoneal (RP), and subcutaneous (SC) fat pads and of the liver (scaled to $10 \%$ of actual weight) and heart as influenced by $2 \%$ CLA fed for either 0,5 , or 14 days. *CLA effect $(p$ $<0.01)$. Error bars represent SEM.

unclear. No such interaction was observed in refed mice. CLA tended to increase heat production in refed mice ( $p$ $=0.13$ ), but only when expressed per body weight (Table 1$)$. This effect ( $8 \%$ increase) is similar to the $12 \%$ increase in energy expenditure attributed to CLA by West et al. (4). Perhaps the response we observed was less robust due to the shorter period of CLA consumption in our experiment (9 days vs. 6 weeks). Altogether, the heat loss results indicate that CLA caused either no change or an increase in energy expenditure, while reducing feed consumption. Feed intake was reduced $10.5 \%$ to $12 \%$ by CLA $(p<0.01$; Table 2$)$ in all three lines. This is similar to the $9.6 \%$ reported by West et al. (4). There was no interaction of genetic line and diet.

\section{Body Weight (Trials 1 and 2)}

Consumption of CLA, despite reducing feed intake, did not cause a loss of body weight. During Trial 1, change in body weight between day 1 and day 12 was 2.4, 1.5, and $1.2 \mathrm{~g}$ for mice fed $0,1 \%$, and $2 \%$ CLA, respectively $(\mathrm{SEM}=0.63 ; p>0.37)$. There was no genetic line-bydiet interaction effect on body weight. C57BL/6J mice weighed less than MH or ML mice. This was partly because they were 2 weeks younger, but even at constant age C57BL/6J mice weighed less than MH or ML mice (11). In Trial 2, consumption of CLA had a positive effect on body weight. At the end of the 14-day period, the body weight of mice fed CLA for 0,5 , and 14 days changed $-7.1,1.6$, and $-0.6 \mathrm{~g}$, respectively $(\mathrm{SEM}=2.0 ; p$ $<0.01$ ). 


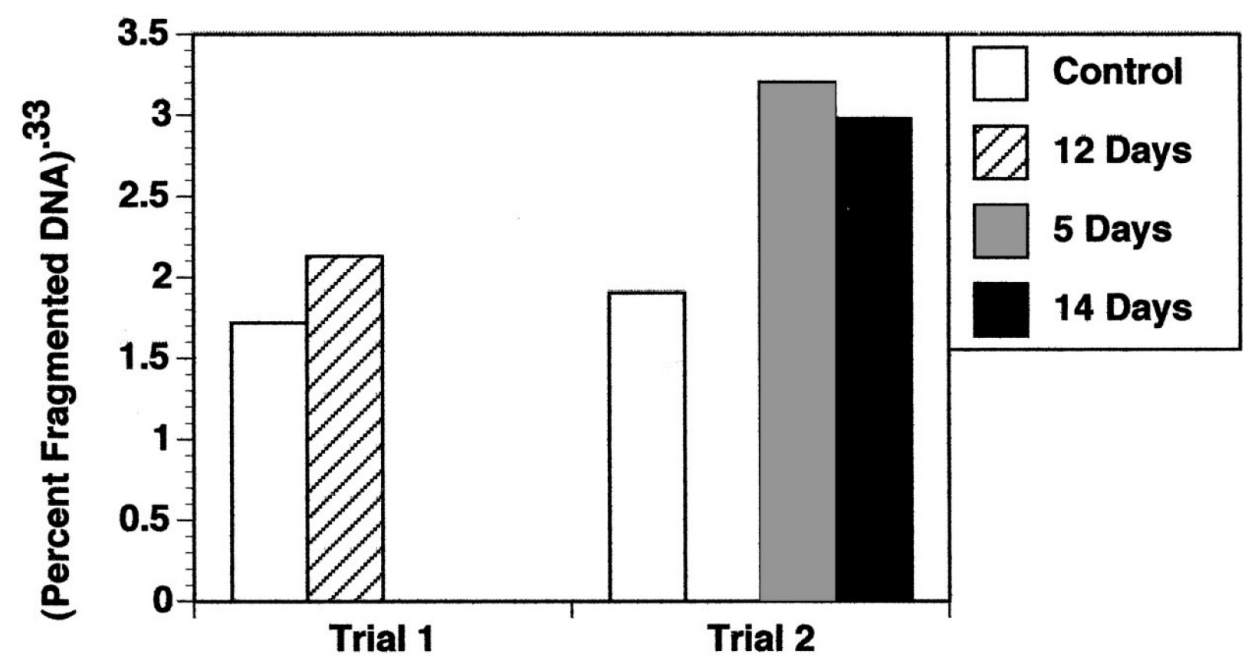

Figure 4. Apoptosis in retroperitoneal fat pads. Effect of CLA pooled across Trials 1 and $2(p<0.01)$. From left to right, bars represent data from $9,12,7,6$, and 7 animals. SE is 0.19.

\section{Tissue Weights (Trials 1 and 2)}

In Trial 1, brown, epididymal, and retroperitoneal fat pad weights were each significantly reduced by dietary CLA $(p<0.01)$. Significant variation in each tissue weight was also accounted for by genetic line $(p<$ $0.01)$, but there was no diet-by-genetic line interaction. Therefore, only the main effects of diet and of line are depicted in Figure 2. Consumption of CLA reduced the weight of epididymal, retroperitoneal, and brown fat pads. This could potentially be explained by an increase in adipose tissue hormone-sensitive lipase activity combined with a reduction of lipoprotein lipase activity as observed by Park et al. (3). These changes in enzyme activity would lead to a net loss of fatty acids from the tissue. Indeed, the brown fat pads of CLA-fed mice in Trial 1 contained less lipid. The lipid content of mice fed 0 , $1 \%$, and $2 \%$ CLA was $52 \%, 42 \%$, and $42 \%$, respectively $(\mathrm{SEM}=1.7 ; p<0.01)$. If fatty acid oxidation was not concurrently stimulated, the circulation of fatty acid to the liver and subsequent re-esterification could potentially cause an increase in liver weight. Our CLA-fed mice in Trial 1 tended to exhibit increased liver weight $(7.6 \% ; p<$ 0.10 ). West et al. (4) observed that feeding mice 1\% CLA for 6 weeks caused liver weight to increase by $22 \%$. The lipid content of livers from mice fed $0,1 \%$, and $2 \%$ CLA was $10.7 \%, 11.4 \%$, and $12.9 \%$, respectively (SEM $=1.4 \%$; $p>0.5$ ). Therefore, any increase in liver weight that may have occurred in our mice due to CLA intake does not appear to have resulted from lipid accumulation. Nevertheless, CLA intake dramatically reduced the weight of fat pads. The relatively small reduction in feed intake by CLA-fed mice during the 12 days probably does not account for the fat loss. Others have argued this point (3) (4), and in studies using mild feed restriction, we have not observed changes in fat pad weight (our unpublished observations). Normally fat depletion due to feed restriction is accompanied by a reduction in body weight in mature animals; we did not observe such a reduction in this study.

In Trial 2, brown, epididymal, retroperitoneal, and subcutaneous fat pads were all reduced in CLA-fed animals $(p<0.01$; Figure 3$)$. The effect of CLA was apparent after only 5 days of continuous consumption. The weight of fat pads after 5 days of CLA intake was not different $(p>0.10)$ from the weight of corresponding pads on day 14. In contrast, heart and liver weights were not affected by dietary CLA.

\section{Apoptosis (Trials 1 and 2)}

Apoptosis was increased in the retroperitoneal fat pads of mice fed 2\% CLA compared with those consuming the control diet (Figure 4; $p<0.01$ ). After either 5 or 14 days of CLA consumption, the incidence of apoptosis was at least 4 -fold greater than the incidence in control mice. This apoptosis cannot be accounted for by the $10 \%$ to $12 \%$ reduction in feed intake. Apoptosis was not observed after restricting feed intake by $60 \%$ (6). CLA has been reported to cause apoptosis of mammary epithelial cells (1), and it reduces cell number in preadipocyte cultures (15) (16). The latter effect has been attributed to inhibition of proliferation and is not due to cytoxicity, as indicated by low media lactate dehydrogenase activity and trypan blue exclusion. However, apoptosis was not specifically assayed (16). We do not know whether apoptosis can be detected by trypan blue exclusion but assume that it does not cause release of intracellular enzymes. Our observation that CLA induces apoptosis in adipose tissue is consistent with two recent reports. First, dietary CLA caused apoptosis in mouse adipose tissue (17). Second, addition of CLA caused apoptosis in cultured 3T3-L1 cells (18). We conclude that dietary CLA can cause apoptosis in mouse adipose tissue. 
Given the incidence of obesity among humans, the fact that CLA selectively reduces body fat deposits (versus lean), and the incomplete understanding of how CLA mediates this effect, the observation that CLA promotes apoptosis in adipose tissue warrants attention.

\section{Acknowledgments}

This project was supported by an Undergraduate Honors Research Grant awarded to C.A.C. by the University of Nebraska Agricultural Research Division. The M16 strain mice were kindly provided by Drs. E. Eisen and D. Pomp.

\section{References}

1. Ip, M. M., Masso-Welch, P. A., Shoemaker, S. F., Shea-Eaton, W. K., Ip, C. (1999) Conjugated linoleic acid inhibits proliferation and induces apoptosis of normal rat mammary epithelial cells in primary culture. Exp Cell Res 250: 22-34.

2. Houseknecht, K. L., Vanden Heuvel, J. P., Moya-Camarena, S. Y., et al. (1998) Dietary conjugated linoleic acid normalizes impaired glucose tolerance in the Zucker diabetic fatty fa/fa rat. Biochem Biophys Res Commun 244: 678-682.

3. Park, Y., Albright, K. J., Liu, W., Storkson, J. M., Cook, M. E., Pariza, M. W. (1997) Effect of conjugated linoleic acid on body composition in mice. Lipids 32: 853-858.

4. West, D. B., Delany, J. P., Camet, P. M., Blohm, F., Truett, A. A., Scimeca, J. (1998) Effects of conjugated linoleic acid on body fat and energy metabolism in the mouse. Am J Physiol 275: R667-R672.

5. DeLany, J. P., Blohm, F., Truett, A. A., Scimeca, J. A., West, D. B. (1999) Conjugated linoleic acid rapidly reduces body fat content in mice without affecting energy intake. Am J Physiol 276: R1172-R1179.

6. Qian, H., Azain, M. J., Compton, M. M., Hartzell, D. L., Hausman, G. J., Baile, C. A. (1998) Brain administration of leptin causes deletion of adipocytes by apoptosis. Endocrinology 139: 791-794.

7. Nielsen, M. K., Jones, L. D., Freking, B. A., DeShazer, J. A. (1997) Divergent selection for heat loss in mice: I. Selection applied and direct response through fifteen generations. J Anim Sci 75: 1461-1468.

8. Nielsen, M. K., Freking, B. A., Jones, L. D., Nelson, S. M., Vorderstrasse, T. L., Hussey, B. A. (1997) Divergent selection for heat loss in mice: II. Correlated responses in feed intake, body mass, body composition, and number born through fifteen generations. J Anim Sci 75: 1469-1476.

9. Eisen, E. J. (1975) Population size and selection intensity effects on long-term selection response in mice. Genetics 79: 305-323.

10. Eisen, E. J. (1987) Effects of selection for rapid postweaning gain on maturing patterns of fat depots in mice. J Anim Sci 64: 133-147.

11. Moody, D. E., Pomp, D., Nielsen, M. K. (1997) Variability in metabolic rate, feed intake, and fatness among selection and inbred lines of mice. Genet Res 70: 225-235.

12. Folch, J., Lees, M., Sloan-Stanley, G. H. (1957) A simple method for the isolation and purification of total lipids from animal tissues. J Biol Chem 224: 497-509.

13. SAS Institute Inc (1991) SAS Language and Procedures: Usage 2, Version 6. 1st ed, SAS Institute Inc Cary, NC 891-996.

14. Himms-Hagen, J. (1997) On raising energy expenditure in ob/ob mice. Science 276: 1132-1133.

15. Brodie, A. E., Manning, V. A., Ferguson, K. R., Jewell, D. E., Hu, C. Y. (1999) Conjugated linoleic acid inhibits differentiation of pre- and post-confluent 3T3-L1 preadipocytes but inhibits cell proliferation only in preconfluent cells. J Nutr 129: 602-606.

16. Satory, D. L., Smith, S. B. (1999) Conjugated linoleic acid inhibits proliferation but stimulates lipid filling of murine 3T3-L1 preadipocytes. J Nutr 129: 92-97.

17. Tsuboyama-Kasaoka, N., Takahashi, M., Tanemura, K., et al. (2000) Conjugated linoleic acid supplementation reduces adipose tissue by apoptosis and develops lipodystrophy in mice. Diabetes 49: 1534-1542.

18. Evans, M., Geigerman, C., Cook, J., Curtis, L., Kuebler, B., McIntosh, M. (2000) Conjugated linoleic acid suppresses triglyceride accumulation and induces apoptosis in 3T3-L1 preadipocytes. Lipids 35: 899-910. 